\title{
Fermentation of Municipal Primary Sludge: Effect of SRT and Solids Concentration on Volatile Fatty Acid Production
}

\author{
Alberto Bouzas ${ }^{1}$, Carmen Gabaldón², Paula Marzal², Josep Manuel Penya-roja² \\ and Aurora Seco ${ }^{2 *}$ \\ ${ }^{1}$ Departamento de Ingeniería Hidráulica y Medio Ambiente, Universidad Politécnica de Valencia. Apdo. 22002, \\ Valencia, Spain. \\ ${ }^{2}$ Departamento de Ingeniería Química, Universitat de València. Dr. Moliner 50, 46100 Burjassot, Valencia, Spain. \\ FAX 34-963864898.
}

\begin{abstract}
Laboratory bench-scale experiments were conducted to investigate the performance of primary sludge fermentation for volatile fatty acids production. Primary sludges from two major wastewater treatment plants located in Valencia (Pinedo and Carraixet) were used. Experiments were performed at solids retention times between 4 and 10 days, and total volatile solids concentrations between $0.6 \%$ and 2.8 $\%$. Operation at two temperatures $\left(20^{\circ} \mathrm{C}\right.$ and $\left.30^{\circ} \mathrm{C}\right)$ was also checked. Results indicated the importance of feed sludge characteristics on volatile fatty acids yields, being approximately double for Carraixet wastewater treatment plant sludge than for Pinedo one. In both cases, higher volatile fatty acids yields were observed at higher total volatile solids concentrations. Solids retention times above 6 days scarcely improve volatile fatty acids yields, while experiments conducted at 4 days of solids retention times shown an important decrease in volatile fatty acids yields. On raising temperature an increase in volatile fatty acids yields was observed, mainly due to an improvement of the hydrolysis of particulate organic matter.
\end{abstract}

KEYWORDS: Fermentation, Primary sludge, Solids retention time, Volatile fatty acids

\section{INTRODUCTION}

Phosphorus removal from domestic and industrial wastewater has become one of the objectives of wastewater treatment in order to minimize eutrophication problems in natural water bodies. For this purpose, enhanced biological phosphorus removal (EBPR) process is nowadays a feasible alternative to chemical phosphorus precipitation. Besides, volatile fatty acids (VFA) have been demonstrated to be the most suitable carbon substrates for the EBPR process $[1,2]$. Acetate and propionate are taken up much faster than $C_{4}$ and $C_{5}$ fatty acids [3]. 
Municipal wastewater has been shown as a potential source of readily biodegradable carbon including VFA [4], thus acid fermentation of primary sludge as a VFA source for the EBPR process has been the subject of several investigations [3, 5-10]. Full scale implementation includes both in-line and side-stream fermentation configurations. In-line process was introduced by Barnard [1] as "activated primary sedimentation tank” (APST). It is, essentially, a primary clarifier with acid fermentation in the sludge blanket and VFA elutriation by recycling the sludge underflow back to the primary clarifier. Low VFA production and disturbances in primary sedimentation tank performance reduce APST applicability. On the other hand, side-stream configurations, with primary sludge feeding, usually comprise a two-stage operation: a separate complete-mix fermenter coupled to a thickener or to a primary sedimentation tank [1, 11-13]). Static fermentation in the thickener has also been investigated [5, 6, 14, 15]

Research on the acid phase of anaerobic digestion over the years has indicated a great dependence of VFA production on solids retention time (SRT), $\mathrm{pH}$, temperature and wastewater characteristics. Eastman and Ferguson [16] identified hydrolysis of particulate organic matter to soluble substrate as the rate-limiting step during the acid generation phase of anaerobic digestion. Lilley et al. [17] concluded that VFA formation was first order with a maximum potential conversion of influent sludge COD to VFA of $17 \%$ at $20^{\circ} \mathrm{C}$ and SRT less than $10 \mathrm{~d}$. Elefsiniotis and Oldham [14] studied the effect of HRT, SRT, pH and reactor configuration. VFA production ranged from 0.08 to $0.26 \mathrm{mg}$ VFA (HAc) $\mathrm{mg}^{-1} \mathrm{VS}$ fed. Highest production rates occurred at SRT between 15 and 20 days. At 5 days SRT, a significant yield reduction was observed. Skalsky and Daigger [6] obtained from bench-scale fermentation tests, VFA yields ranged between $6 \%$ and $26 \%$ of volatile solids fed with $2-6$ days SRT range, 0.42-6.0 \% fermenter solids concentration range, and temperatures varied between $14-23{ }^{\circ} \mathrm{C}$. Higher yields were observed at higher SRT, lower solids concentration and higher temperatures. Banister and Pretorious [18] observed that acid fermentation proceeded rapidly at retention times of less than 6 days, with VFA yields of 18\% of the total influent volatile suspended solids concentration after 6 days. Acid production kinetics seems to derive from sludge solids biodegradability, so thus empirically design criteria are needed to investigate full-scale implementations.

The aim of this study is to investigate the primary sludge fermentation in bench-scale reactors for two major wastewater treatment plants (WWTP) located in Valencia (Spain). This work focused on basic design and operation parameters including VFA yield at different SRT, solids concentrations and temperatures. Results from this study can be applied to operate a 
separate complete-mix fermenter of the two-stage configuration. This research is a part of a project in development that includes pilot plant studies to evaluate fermentation-elutriation methods, settleability of the elutriated fermented sludge and the use of VFA products in the EBPR process.

\section{MATERIALS AND METHODS}

Bench-scale experiments were conducted using four methacrylate reactors with a working volume of $2.77 \mathrm{l}$. The reactors were equipped with mechanical agitation to maintain solids in suspension and $\mathrm{pH}$ registration. Studies were performed to examine VFA yield at different SRT, solids concentrations and temperatures. SRT ranged between 4 days and 10 days. Solids concentration was varied in the range $1 \%$ to $5 \%$. The reactors were incubated at constant temperature of $20^{\circ} \mathrm{C} \pm 0.5^{\circ} \mathrm{C}$ and $30^{\circ} \pm 0.5^{\circ} \mathrm{C}$.

The experiments were conducted with two primary sludges from two major municipal wastewater treatment plants located in Valencia (Spain). The first sludge was obtained from the Pinedo WWTP (576000-population equivalent) and the second from the Carraixet WWTP (118000-population equivalent). Fresh primary sludge was weekly collected from the gravity thickener, analyzed for total solids (TS), total volatile solids (TVS), total volatile fatty acids (VFA), total and soluble chemical oxygen demand (COD and COD $_{\text {sol }}$ ), total and soluble phosphorus, and ammonia, and cold stored at $6^{\circ} \mathrm{C}$ to minimize degradation. A separate study on the effect of storage showed that no appreciable modification in the soluble COD and VFA occurred during 10 days of storage.

The four reactors were daily fed with raw sludge previously diluted with tap water to adjust the feed TS concentration. For each experiment, after seven days of initial operation, performance was assessed by measuring $\mathrm{pH}$ daily, and VFA, TS, TVS, COD and alkalinity twice a week. VFA and alkalinity were determined by the 5-point titration method [19]. The other analytical parameters were measured according with Standard Methods [20]. Reactors were operated a minimum of three times the SRT and stationary condition was assummed when variation in VFA was less than $15 \%$. Once stationary condition was achieved, VFA composition was analyzed by using a Varian Star 3400 CX gas chromatograph with a flame ionization detector. The chromatographic column was TR-FFAP $15 \times 0.53 \mathrm{~mm} \times 1.0 \mu \mathrm{m}$ film for volatile acids. 


\section{RESULTS AND DISCUSSION}

\section{Feed Characteristics}

The characteristics of the two sludges used in this study are summarized in Table 1. For both sludges, TS concentration and TVS percentage are in the typical range for gravity thickened primary sludge, but differences in biodegradability characteristics are observed. Pinedo sludge presents higher organic matter concentration $(\sim 17 \%$ greater than Carraixet sludge) but lower soluble organic matter concentration (mean $\mathrm{COD}_{\text {sol }} / \mathrm{COD}$ percentage 2.9 for Pinedo sludge and 8.6 for Carraixet sludge) indicating lower hydrolyzed rates for the thickened Pinedo sludge. However, thickened Pinedo sludge presents a higher fermentation degree, with mean VFA/COD ${ }_{\text {sol }}$ of $60.4 \%$ against $52.1 \%$ in the Carraixet sludge. Besides, both sludges presented a variable composition, derived from WWTP performance, indicating differences in the hydrolysis and fermentation degrees at collection.

VFA Production and Particulate Organic Carbon Solubilization

Results of acid fermentation of the two primary sludges (VFA production) are shown in Tables 2 and 3 along with the experimental conditions and analytical results. Due to the variable composition of the collected feed sludge, overall yields, expressed as mass of fermenter effluent per unit of feed TVS, have been calculated, both for VFA and for soluble COD productions, to evaluate the acid fermentation potential.

For the experiments performed at $20^{\circ} \mathrm{C}$, the maximum VFA yields observed were 0.11 mg VFA (HAc) $\mathrm{mg}^{-1}$ TVS feed for Pinedo sludge and 0.18 mg VFA (HAc) $\mathrm{mg}^{-1}$ TVS feed for Carraixet sludge, both corresponding to the higher SRT (10 days) and TVS feed (2.4 - $2.7 \%$ ). Minimum observed yields were 0.06 mg VFA (HAc) $\mathrm{mg}^{-1}$ TVS feed, for Pinedo (1.3\% TVS and 6 days SRT) and 0.07 mg VFA (HAc) $\mathrm{mg}^{-1}$ TVS feed, for Carraixet (1.6\% TVS feed and 4 days SRT). These values are similar with those previously reported $[6,14,17,18]$. As can be observed, VFA yield reported here strongly depends on the sludge composition. For similar experimental conditions (SRT and TVS feed concentration) Carraixet VFA yields are nearly twice than Pinedo yields. Effects of fed TVS, SRT and temperature are discussed later.

Similar tendencies to those observed for VFA production were obtained for particulate organic carbon solubilization. Maximum soluble COD productions were obtained for the maximun TVS and temperature. Results ranged between $0.12-0.20 \mathrm{mg}$ soluble COD $\mathrm{mg}^{-1}$ 
TVS feed for Pinedo sludge and 0.10-0.33 mg soluble COD mg ${ }^{-1}$ TVS feed for Carraixet sludge. As for VFA production, hydrolysis of particulate COD is highly influenced by the primary sludge characteristics. The hydrolysis potential was nearly double for Carraixet than for Pinedo.

\section{Effect of TVS and SRT}

Effects of TVS concentration on VFA production and COD solubilization are shown in Figures 1 and 2. VFA production and COD solubilization of Pinedo sludge have been well correlated with TVS concentration for all the experimental conditions (SRT between 4 and 10 days). For this sludge, TVS seems to be the operational parameter for practical acidfermentation design. Although some authors reported that dilute sludges reduce the inhibitory effect of fermentation products or substrate on the acidogenic digestion $[6,18]$, no inhibitory effects of fermentation products at high solids concentration (those from gravity thickeners) have been observed. For the Carraixet sludge a dependence of VFA production and COD solubilization on TVS concentration and SRT is observed. Results for 6 days of SRT have been linear correlated, showing, also, no inhibitory effects at high TVS concentration. Anycase, both VFA production and COD solubilization were higher for Carraixet sludge than for Pinedo one.

Importance of the hydrolysis of particulate organic matter to soluble substrate in the acid-fermentation process can be derived from Figure 3. In this Figure, VFA production/ COD solubilization ratio has been represented for both sludges. As can be observed, appreciable differences have been found. For Pinedo sludge, a constant ratio of 0.576 (standard deviation of 0.036) was obtained for runs at feed TVS concentration higher than $1.7 \%$, being the dispersion most likely attributable to variation in the sludge composition between tests. This constancy could be explained on the basis of the hydrolysis as the ratelimiting step. Runs performed at low feed TVS concentration (1.3\%) present a mean value of $0.478 \mathrm{VFA} /$ soluble COD ratio, indicating that at low feed TVS concentration, fermentation problems appeared and the drop in solids concentration will start to limit the VFA levels attainable. For Carraixet sludge, a mean VFA/soluble COD ratio of 0.610 can be assumed (standard deviation of 0.075 ), with the exceptions of runs $1 \mathrm{~A}$ and $3 \mathrm{~A}$, for which extreme operational conditions related to low SRT or to low feed TVS were used. At lower feed TVS concentration (0.6\%), particulate organic matter was broken down less efficiently, also reducing the VFA yield. The differences observed between the two sludges, Pinedo and 
Carraixet, point out the importance on empirical for the evaluation of the acidogenic sludge digestion.

Effects of SRT on VFA production and COD solubilization are shown in Figures 4 and 5 respectively. Total VFA yield, (Figure 4) and total soluble COD yield, (Figure 5) have been represented as a function of SRT for different feed TVS concentrations for both sludges. In these Figures, the greater fermentation potential of the Carraixet sludge is also observed. For Pinedo sludge, acid fermentation showed a slight dependence on SRT. For runs at 2.4$2.7 \%$ feed volatile solids concentration, it is significant the minimum yield of $0.082 \mathrm{mg}$ HAc $\mathrm{mg}^{-1}$ TVS feed observed at 4 days, by comparison to the values of $0.093,0.092$ and $0.102 \mathrm{mg}$ HAc mg ${ }^{-1}$ TVS feed obtained at 6, 8 and 10 days, respectively. From Figure 5, similar trends were obtained for soluble COD yields, 0.157 - 0.182 mg soluble COD mg-1 TVS feed for the SRT range of 4 - 10 days. These data suggest not exceeding 6 days of SRT for fermentation sludge design. Figure 4 also indicates that higher VFA yields were obtained at higher feed TVS concentration, so high solid concentrations in the fermenter/thickener systems could therefore be used ( $\sim 4-5 \%$ of TS). Indeed, there may be a minimum of solids concentration below that acid fermentation process drastically drops. VFA yield decreased approximately a $34 \%$ when feed TVS decreased from 2.7 to $1.3 \%$ for 6 days of SRT. A similar trend was observed for the hydrolysis of particulate organic matter, with a decrease of $23 \%$ of soluble COD yield, for the same tests.

For Carraixet sludge, acid fermentation showed a dependence on SRT. VFA yield increased from 0.141 to $0.183 \mathrm{mg} \mathrm{HAc} \mathrm{mg}^{-1}$ TVS feed at 4 and 10 days respectively for 2.4$2.6 \%$ volatile solids. Value for the run of 4 days of SRT presented an important decrease in comparison to the values obtained at 6, 8 and 10 days. Besides, the minimum VFA yield of $0.074 \mathrm{mg} \mathrm{HAc} \mathrm{mg}^{-1}$ TVS feed was obtained at 4 days for $1.6 \%$ volatile solids, being less than those obtained at SRT of 6 days for lower TVS concentrations. The decrease on the VFA yields at 4 days of SRT could be explained based on the decrease of the soluble COD yields obtained for these operational conditions. From Figure 5, soluble COD yield remained approximately constant, with an average value of $0.322 \mathrm{mg}$ soluble COD $\mathrm{mg}^{-1} \mathrm{TVS}^{-}$feed for the runs at 6-10 days of SRT for 2.4\%. So that, in the 6-10 days of SRT range, the increase of the VFA yield may be due to the higher SRT that contributes to enhance the fermentation of the soluble substrate. Other side, for the same feed TVS concentration, the run at 4 days of SRT showed a yield of $0.243 \mathrm{mg}$ soluble COD $\mathrm{mg}^{-1}$ TVS feed, indicating a decrease of the hydrolysis of particulate organic matter that directly affects to the VFA yield. Similar results were obtained for the run at SRT 4 days and $1.6 \%$ feed TVS concentration. Figures 4 and 5 
also indicate that higher VFA and soluble COD yields were obtained at higher feed TVS concentration. A linear dependence is observed for the runs performed at 6 days SRT in the $1.2-2.4 \%$ volatile solids range. At low volatile solids concentration (0.6\%) the decrease in the VFA and soluble COD yields is clearly out of the direct dependence obtained at higher feed TVS concentrations. As above mentioned, dilution of the Carraixet sludge caused hydrolysis failure, decreasing the sludge fermentation potential.

From these results, similar conclusions related to the SRT and the TVS concentration design criteria can be derived than for Pinedo sludge: 6 days of SRT and fermentation of the thickened sludge ( 3-4 \% of TS).

\section{Characterization of Volatile Fatty Acids}

Chromatographic analysis results are shown in Table 4. The VFA produced in the fermentation of both sludges consists mainly of acetic acid and propionic acid. n-Butyrate, iso-butyrate, methyl butyrate and n-valeriate represent a minority fraction. Although the two sludges shown differences in composition and VFA yields, VFA distribution values are relatively close for the acetic and propionic percentages. Such values are consistent with previous research where acetic acid ranges from $33 \%$ to $73 \%$ and propionic acid from $28 \%$ to $44 \%[3,6,10]$.

Experimental tests running with dilute sludges (3P and 4P, and 3A) which were related to problems on the fermentation, presented a deviation of the mean values, with a higher percentage of acetic acid and a lower percentage of propionic acid. Thus, low feed TVS concentrations affect in a different extension to the specific hydrolysis and fermentation pathways of the complex substrates present on the wastewater, sugars, proteins and lipids. Metabolic pathways to propionic acid seem to be inhibited with dilution of the thickened sludge. This phenomena is observed in a greater degree for the Carraixet sludge.

\section{Effect of Temperature}

Effect of temperature was investigated for Carraixet sludge. Runs 8A and 9A were carried out at $20^{\circ} \mathrm{C}$, and runs $11 \mathrm{~A}$ and $12 \mathrm{~A}$ were operated at $30^{\circ} \mathrm{C}$ for feed TVS values fairly constant and SRT of 6 and 8 days. VFA and soluble COD yields are presented in Table 3 and in Figure 6. The VFA yield at $30^{\circ} \mathrm{C}$ was approximately $4 \%$ and $11 \%$ greater than that observed at $20^{\circ} \mathrm{C}$, for SRT of 6 and 8 days, respectively. The same trend is followed by the COD yield, with an increase of 21\% and 23\% for 6 and 8 days of SRT respectively. For this sludge, increase in temperature promotes the hydrolysis process, contributing to improve the 
fermentation of the sludge. Any case, experience in pilot plant should be required to evaluate the effect of temperature on the settling characteristics.

Preliminary evaluation of primary sludge fermentation as VFA source for phosphorus removal

From experimental yields and bibliographic VFA (HAc) $\mathrm{g}^{-1} \mathrm{P}_{\text {removed }}$ ratio a preliminary estimation of the application of sludge fermentation as extra source of VFA for EBPR process has been performed for both WWTP. A factor of $8 \mathrm{~g}$ VFA (HAc) $\mathrm{g}^{-1} \mathrm{P}_{\text {removed }}$ (soluble phosphorus) seems to be a reasonable value [10, 14, 21]. For Pinedo sludge, 1.5-1.9 ppm of soluble phosphorus could be removed. For Carraixet sludge, 3.6-4.5 ppm of soluble phosphorus could be removed. These results indicate that for Pinedo WWTP, internal VFA production could reach approximately 30-35 \% of external carbon source for EBPR. Other side, for Carraixet WWTP, internal VFA production seems to be a feasible alternative to external carbon source for EBPR, since laboratory results show that $90 \%$ of required VFA could be obtained by primary sludge fermentation. To check results obtained for Carraixet WWTP, pilot plant experiments comprising both fermentation-elutriation of primary sludge and EBPR process, are in development.

\section{CONCLUSIONS}

Fermentation of two primary sludge types from different WWTP (Pinedo and Carraixet) were investigated. Results shown the importance of sludge characteristics on the efficiency of VFA production, thus variable sludge solids degradability would seem to determine the sludge VFA potential. Although, optimum operation conditions were similar for both sludges at $20^{\circ} \mathrm{C}$ : SRT not longer than 6 days and no dilution of primary thickened sludge; VFA yields for Carraixet WWTP were approximately twice than for Pinedo one. No inhibitory effects were observed at maximum feed TVS concentrations and experiments conducted with diluted sludges (1:2.5 for Pinedo, 1:4 for Carraixet) shown an important decrease in the VFA yields. For each WWTP, the VFA composition is independent of the operational conditions, SRT and solids concentration. Only, tests performed with diluted sludges, where fermentation problems occurred, shown an anomalous increase of the acetic percentage, indicating a possible inhibition of the metabolic pathways for propionic acid. For Carraixet sludge, an increment in temperature from $20^{\circ} \mathrm{C}$ to $30^{\circ} \mathrm{C}$, improved the hydrolysis of the particulate organic matter, causing higher VFA yields. 
Although further pilot scale plant experiments will be needed in the future to define the final operation of the primary sludge fermentation/elutriation, results from laboratory bench-scale show that primary sludge fermentation should be an alternative to the external carbon source to achieve satisfactory phosphorus removal in the Carraixet WWTP.

\section{ACKNOWLEDGEMENTS}

Financial support by MEC/CICYT, Spain, (Project No. AMB98-0881) is acknowledged.

Support by Entitat de Sanejament d'Aigües Residuals de la Comunitat Valenciana is acknowledged. Emarsa (Pinedo WWTP) and Sociedad de Agricultores de la Vega (Carraixet WWTP) cooperation is also acknowledged.

\section{REFERENCES}

1. Barnard, J.L. Activated primary tanks for phosphate removal. Water SA, 10, 121-126, (1984).

2. Gerber, A. Mostert, E.S., Winter, C.T. and Villiers, R.H. Interactions between phosphate, nitrate and organic substrate in biological nutrient removal processes. Water Sci. Technol., 19, 1873-194, (1987).

3. Moser-Engeler, R., Udert, K.M., Wild, D. and Siegrist, H. Products from primary sludge fermentation and their suitability for nutrient removal. Water Sci. Technol. 38, 265-273, (1998).

4. Eastman, J.A. Solubilisation of organic carbon during the acid phase of anaerobic digestion. Ph.D. Thesis, University of Washington (1977).

5. Rabinowitz, B. and Oldham, W.K. Excess biological phosphorus removal in the activated sludge process using primary sludge fermentation. Can. J. Civil Eng., 13, 345-351, (1986). 
6. Skalsky D.S. and Daigger, G.T. Wastewater solids fermentation for volatile acid production and enhanced biological phosphorus removal. Water Environ. Res., 67, 230237, 1995.

7. Comeau, Y., Lamarre, D., Roberge, F., Perrier, M., Desjardins, G., Hade, C. and Mayer, R. Biological nutrient removal from a phosphorus-rich pre-fermented industrial wastewater. Water Sci. Technol., 34, 169-177, (1996).

8. Danesh, S. and Oleszkiewicz, J.A. Volatile fatty acid production and uptake in biological nutrient removal systems with process separation. Water Environ. Res., 69, 1106-1111, (1997).

9. Christensson, M., Lie, E., Jönsson, K., Johansson, P. and Welander, T. Increasing substrate for polyphosphate-accumulating bacteria in municipal wastwater through hydrolysis and fermentation of sludge in primary clarifiers. Water Environ. Res, 70, 138145, (1998).

10. Mavinic, D.S., Mahendraker, V., Doucette, D., Rabinowitz, B., Barnard, J.L. and Koch, F.A. Feasibility of using high-rate, on-line, fixed-film fermenters for SCVFA generation in a BNR process train. Environ. Technol., 21, 941-952, (2000).

11. Wedi, D. Effects of an activated primary settling tank on biological phosphorus removal. Water Sci. Technol., 26, 2199-2202, (1992).

12. Lötter, L.H. and Pitman, A.R. Improved biological phosphorus removal resulting from the enrichment of reactor feed with fermentation products. Water Sci. Technol., 26, 943-953, (1992).

13. Hatziconstantinou, G.J., Yannakopoulos, P. and Andreadakis, A. Primary sludge hydrolysis for biological nutrient removal. Water Sci. Technol., 34, 417-423, (1996).

14. Elefsiniotis, P. and Oldham, W.K. Substrate degradation patterns in acid-phase anaerobic digestion of municipal primary sludge. Environ. Technol. 15, 741-751, (1994). 
15. Moser-Engeler, R., Kühni, M., Bernhard, C. and Siegrist, H. fermentation of raw sludge on an industrial scale and applications for elutriating its dissolved products and nonsedimentable solids. Water Res. 33, 3503-3511, (1999).

16. Eastman J.A. and Ferguson, J.F. Solubilization of particulate organic matter during the acid-phase of anaerobic digestion. J. Water Pollut. Control Fed., 53, 352-366, (1981).

17. Lilley, I.D., Wenztel, M.C., Loewenthal, R.E. and Marais, G.vR. Acid fermentation of primary sludge at $20^{\circ} \mathrm{C}$. Res. Rep. W64. Department of Civil Engineering, University of Cape Town, South Africa (1990).

18. Banister S.S. and PretoriousW.A. Optimisation of primary sludge acidogenic fermentation for biological nutrient removal. Water SA, 21, 35-41, (1998).

19. Moosbrugger, R.E., Wentzel, M.C., Ekama, G.A. and Marais, G.vR. Simple titration procedures to determine $\mathrm{H}_{2} \mathrm{CO}_{3}{ }^{*}$ alkalinity and short-chain fatty acids in aqueous solutions containing known concentrations of ammonium, phosphate and sulphide weak acid/bases. WCR Report No. TT 57/92. Res. Rep. W74, University of Cape Town, South Africa (1992).

20. APHA, AWWA and WEF. Standard Methods for the Examination of Water and Wastewater. $20^{\text {th }}$ ed., Am. Public Health Assoc., Washington, D.C. (1998).

21. Münch, E.v. and Koch, F.A. A survey of prefermenter design, operation and performance in Australia and Canada. Water Sci. Technol., 39, 105-112, (1999). 
Table 1. Characteristics of the thickened primary sludge fed to the bench-scale fermenters.

\begin{tabular}{|c|c|c|c|c|c|c|}
\hline \multirow[t]{2}{*}{ Parameter } & \multicolumn{3}{|c|}{$\begin{array}{c}\text { Pinedo WWTP } \\
\text { (September } 1999 \text { to March 2000) }\end{array}$} & \multicolumn{3}{|c|}{$\begin{array}{c}\text { Carraixet WWTP } \\
\text { (February } 2000 \text { to June 2000) }\end{array}$} \\
\hline & Mean & Minimum & Maximum & Mean & Minimum & Maximum \\
\hline $\mathrm{TS}\left(\mathrm{mg} \mathrm{l}^{-1}\right)$ & 50075 & 40070 & 60210 & 48570 & 43650 & 52690 \\
\hline TVS (mg l-1) & 30825 & 24760 & 39640 & 31890 & 27720 & 35250 \\
\hline $\mathrm{COD}\left(\mathrm{mg} \mathrm{l}^{-1}\right)$ & 63900 & 49500 & 82500 & 52700 & 42500 & 62600 \\
\hline $\mathrm{COD}_{\mathrm{sol}}\left(\mathrm{mg} \mathrm{l}^{-1}\right)$ & 1840 & 1380 & 2490 & 4510 & 3370 & 5790 \\
\hline VFA $\left(\mathrm{mg} \mathrm{l}^{-1}\right)$ & 1111 & 962 & 1372 & 2350 & 1698 & 2964 \\
\hline Total phosphorus (mg l-1) & 208 & 157 & 273 & 172 & 130 & 286 \\
\hline Soluble phosphorus (mg l $\mathrm{l}^{-1}$ ) & 115 & 101 & 135 & 46.3 & 18.5 & 72.4 \\
\hline Ammonia as $\mathrm{N}\left(\mathrm{mg} \mathrm{l}^{-1}\right)$ & 106 & 68 & 166 & 359 & 245 & 482 \\
\hline $\mathrm{pH}$ & 5.88 & 5.81 & 6.04 & 6.04 & 5.60 & 6.39 \\
\hline Alkalinity (mg l-1 as $\mathrm{CaCO}_{3}$ ) & 341 & 220 & 483 & 432 & 332 & 548 \\
\hline
\end{tabular}


Table 2. Experimental conditions, average VFA yields and soluble COD yields for Pinedo primary sludge fermentation

\begin{tabular}{|c|c|c|c|c|c|c|c|c|}
\hline Run & $\begin{array}{c}\mathrm{T} \\
\left({ }^{\circ} \mathrm{C}\right)\end{array}$ & $\begin{array}{l}\text { SRT } \\
\text { (d) }\end{array}$ & $\begin{array}{c}\text { Feed } \\
\text { TS } \\
(\%)\end{array}$ & $\begin{array}{l}\text { Feed } \\
\text { TVS } \\
(\%)\end{array}$ & $\begin{array}{l}\text { Effluent VFA } \\
\text { (mg HAc l-1) }\end{array}$ & $\begin{array}{l}\text { Effluent } \\
\text { COD }_{\text {sol }} \\
\left(\mathrm{mg} \mathrm{l}^{-1}\right)\end{array}$ & $\begin{array}{c}\text { VFA yield } \\
\left.\text { (mg VFA(HAc) } \mathrm{mg}^{-1} \mathrm{TVS}\right)\end{array}$ & $\begin{array}{c}\text { Soluble COD } \\
\text { yield } \\
\left.\text { (mg COD } \text { sol } \mathrm{mg}^{-1} \mathrm{TVS}\right)\end{array}$ \\
\hline $1 \mathrm{P}$ & 20 & 4 & 3.12 & $\begin{array}{c}1.99 \\
(0.03)\end{array}$ & $\begin{array}{l}1694 \\
(234)\end{array}$ & $\begin{array}{l}2800 \\
(247)\end{array}$ & 0.085 & 0.141 \\
\hline $2 \mathrm{P}$ & 20 & 4 & 3.98 & $\begin{array}{c}2.61 \\
(0.06)\end{array}$ & $\begin{array}{l}2148 \\
(284)\end{array}$ & $\begin{array}{r}4110 \\
(77)\end{array}$ & 0.082 & 0.157 \\
\hline $3 P$ & 20 & 6 & 2.04 & $\begin{array}{c}1.32 \\
(0.03)\end{array}$ & $\begin{array}{l}760 \\
(28)\end{array}$ & $\begin{array}{l}1630 \\
(141)\end{array}$ & 0.058 & 0.123 \\
\hline $4 \mathrm{P}$ & 20 & 6 & 2.04 & $\begin{array}{c}1.32 \\
(0.03)\end{array}$ & $\begin{array}{l}845 \\
(71)\end{array}$ & $\begin{array}{c}1730 \\
(28)\end{array}$ & 0.064 & 0.131 \\
\hline $5 P$ & 20 & 6 & 4.09 & $\begin{array}{c}2.61 \\
(0.06)\end{array}$ & $\begin{array}{c}2248 \\
(62)\end{array}$ & $\begin{array}{c}3540 \\
(45)\end{array}$ & 0.086 & 0.136 \\
\hline $6 \mathrm{P}$ & 20 & 6 & 4.04 & $\begin{array}{c}2.68 \\
(0.06)\end{array}$ & $\begin{array}{c}2390 \\
(92)\end{array}$ & $\begin{array}{l}4260 \\
(165)\end{array}$ & 0.089 & 0.159 \\
\hline $7 \mathrm{P}$ & 20 & 6 & 4.43 & $\begin{array}{c}2.73 \\
(0.14)\end{array}$ & $\begin{array}{l}2628 \\
(243)\end{array}$ & $\begin{array}{r}4750 \\
(69)\end{array}$ & 0.096 & 0.174 \\
\hline $8 \mathrm{P}$ & 20 & 6 & 5.15 & $\begin{array}{c}3.07 \\
(0.33)\end{array}$ & $\begin{array}{c}3314 \\
(130)\end{array}$ & $\begin{array}{l}5420 \\
(150)\end{array}$ & 0.108 & 0.177 \\
\hline $9 \mathrm{P}$ & 20 & 8 & 3.04 & $\begin{array}{c}1.75 \\
(0.08)\end{array}$ & $\begin{array}{l}1563 \\
(84)\end{array}$ & $\begin{array}{r}2800 \\
(39)\end{array}$ & 0.089 & 0.160 \\
\hline $10 \mathrm{P}$ & 20 & 8 & 4.05 & $\begin{array}{c}2.36 \\
(0.19)\end{array}$ & $\begin{array}{c}2018 \\
(50)\end{array}$ & $\begin{array}{l}3710 \\
(127)\end{array}$ & 0.086 & 0.157 \\
\hline $11 \mathrm{P}$ & 20 & 8 & 4.07 & $\begin{array}{c}2.40 \\
(0.13)\end{array}$ & $\begin{array}{l}2320 \\
(280)\end{array}$ & $\begin{array}{c}4580 \\
(27)\end{array}$ & 0.097 & 0.191 \\
\hline $12 \mathrm{P}$ & 20 & 10 & 3.86 & $\begin{array}{c}2.20 \\
(0.11)\end{array}$ & $\begin{array}{l}1880 \\
(48)\end{array}$ & $\begin{array}{c}3220 \\
(71)\end{array}$ & 0.085 & 0.146 \\
\hline $13 \mathrm{P}$ & 20 & 10 & 5.14 & $\begin{array}{c}2.64 \\
(0.15)\end{array}$ & $\begin{array}{c}2480 \\
(47)\end{array}$ & $\begin{array}{l}4350 \\
(227)\end{array}$ & 0.094 & 0.165 \\
\hline $14 \mathrm{P}$ & 20 & 10 & 4.01 & $\begin{array}{c}2.72 \\
(0.08)\end{array}$ & $\begin{array}{c}2998 \\
(55)\end{array}$ & $\begin{array}{l}5400 \\
(100)\end{array}$ & 0.110 & 0.199 \\
\hline
\end{tabular}

Runs 3P, 6P, 11P and 14P are replicates.

Standard deviations at stationary in brackets. 
Table 3. Experimental conditions, average VFA yields and average soluble COD yields for Carraixet primary sludge fermentation

\begin{tabular}{|c|c|c|c|c|c|c|c|c|}
\hline Run & $\begin{array}{c}\mathrm{T} \\
\left({ }^{\circ} \mathrm{C}\right)\end{array}$ & $\begin{array}{l}\text { SRT } \\
\text { (d) }\end{array}$ & $\begin{array}{c}\text { Feed } \\
\text { TS } \\
(\%)\end{array}$ & $\begin{array}{l}\text { Feed } \\
\text { TVS } \\
(\%)\end{array}$ & $\begin{array}{l}\text { Effluent VFA } \\
(\text { mg HAc l-1) }\end{array}$ & $\begin{array}{l}\text { Effluent } \\
\text { COD }_{\text {sol }} \\
\left(\mathrm{mg} \mathrm{l}^{-1}\right)\end{array}$ & $\begin{array}{c}\text { VFA yield } \\
\left(\mathrm{mg} \text { VFA(HAc) } \mathrm{mg}^{-1} \mathrm{TVS}\right)\end{array}$ & $\begin{array}{c}\text { Soluble COD } \\
\text { yield } \\
\left.\text { (mg COD } \text { sol } \mathrm{mg}^{-1} \mathrm{TVS}\right)\end{array}$ \\
\hline $1 \mathrm{~A}$ & 20 & 4 & 2.97 & $\begin{array}{c}1.56 \\
(0.06)\end{array}$ & $\begin{array}{c}1160 \\
(52)\end{array}$ & $\begin{array}{c}1550 \\
(40)\end{array}$ & 0.074 & 0.099 \\
\hline $2 \mathrm{~A}$ & 20 & 4 & 4.09 & $\begin{array}{c}2.60 \\
(0.14)\end{array}$ & $\begin{array}{l}3664 \\
(224)\end{array}$ & $\begin{array}{l}6310 \\
(597)\end{array}$ & 0.141 & 0.243 \\
\hline $3 \mathrm{~A}$ & 20 & 6 & 1.03 & $\begin{array}{c}0.64 \\
(0.04)\end{array}$ & $\begin{array}{l}642 \\
(88)\end{array}$ & $\begin{array}{l}800 \\
(71)\end{array}$ & 0.100 & 0.125 \\
\hline $4 \mathrm{~A}$ & 20 & 6 & 2.00 & $\begin{array}{c}1.24 \\
(0.04)\end{array}$ & $\begin{array}{l}1604 \\
(97)\end{array}$ & $\begin{array}{l}2480 \\
(230)\end{array}$ & 0.129 & 0.200 \\
\hline $5 \mathrm{~A}$ & 20 & 6 & 1.99 & $\begin{array}{c}1.23 \\
(0.05)\end{array}$ & $\begin{array}{c}1578 \\
(42)\end{array}$ & $\begin{array}{l}2630 \\
(183)\end{array}$ & 0.128 & 0.214 \\
\hline $6 \mathrm{~A}$ & 20 & 6 & 3.02 & $\begin{array}{c}1.87 \\
(0.05)\end{array}$ & $\begin{array}{c}2872 \\
(49)\end{array}$ & $\begin{array}{l}4960 \\
(432)\end{array}$ & 0.154 & 0.265 \\
\hline $7 \mathrm{~A}$ & 20 & 6 & 2.99 & $\begin{array}{c}1.85 \\
(0.09)\end{array}$ & $\begin{array}{l}2655 \\
(131)\end{array}$ & $\begin{array}{l}3880 \\
(285)\end{array}$ & 0.144 & 0.210 \\
\hline $8 \mathrm{~A}$ & 20 & 6 & 4.04 & $\begin{array}{c}2.36 \\
(0.15)\end{array}$ & $\begin{array}{l}4048 \\
(218)\end{array}$ & $\begin{array}{l}7500 \\
(650)\end{array}$ & 0.172 & 0.318 \\
\hline $9 \mathrm{~A}$ & 20 & 8 & 4.08 & $\begin{array}{c}2.37 \\
(0.15)\end{array}$ & $\begin{array}{l}4138 \\
(251)\end{array}$ & $\begin{array}{l}7800 \\
(669)\end{array}$ & 0.175 & 0.329 \\
\hline $10 \mathrm{~A}$ & 20 & 10 & 4.05 & $\begin{array}{c}2.37 \\
(0.15)\end{array}$ & $\begin{array}{l}4340 \\
(148)\end{array}$ & $\begin{array}{l}7590 \\
(163)\end{array}$ & 0.183 & 0.320 \\
\hline $11 \mathrm{~A}$ & 30 & 6 & 3.44 & $\begin{array}{c}2.19 \\
(0.12)\end{array}$ & $\begin{array}{l}3913 \\
(211)\end{array}$ & $\begin{array}{l}8420 \\
(168)\end{array}$ & 0.179 & 0.384 \\
\hline $12 \mathrm{~A}$ & 30 & 8 & 3.44 & $\begin{array}{c}2.19 \\
(0.12)\end{array}$ & $\begin{array}{l}4277 \\
(172)\end{array}$ & $\begin{array}{l}8860 \\
(663)\end{array}$ & 0.195 & 0.405 \\
\hline
\end{tabular}

Runs 5A, and 6A are replicates.

Standard deviations at stationary in brackets. 
Table $4 . \quad$ Composition of the VFA fraction (percentages)

\begin{tabular}{lcccccc}
\hline & \multicolumn{2}{c}{ Acetic } & \multicolumn{2}{c}{ Propionic } & \multicolumn{2}{c}{ C4-C6 $_{4}$ acids } \\
& Mean & STD & Mean & STD & Mean & STD \\
\cline { 2 - 7 } Pinedo Sludge & & & & & & \\
Runs 1P, 2P, 5P-14P & 57.4 & 3.3 & 31.3 & 3.9 & 11.3 & 2.0 \\
Runs 3P, 4P & 65.6 & & 21.9 & & 12.6 & \\
Carraixet Sludge & & & & & & \\
Runs 1A, 2A, 4A-10A & 50.2 & 2.6 & 26.5 & 2.2 & 23.3 & 1.9 \\
Run 3A & 89.0 & & 1.5 & & 9.5 & \\
\hline
\end{tabular}

STD is standard deviation. 